\title{
PERAN PENGADILAN AGAMA DALAM PRAKTIK PENYELESAIAN SENGKETA EKONOMI SYARIAH
}

\author{
Syaiful Bahri* \\ *Institut Agama Islam Negeri (IAIN) Madura \\ Jl. Raya Panglegur, KM. 04 Pamekasan. \\ e-mail: bsyaifulbahri62@gmail.com
}

\begin{abstract}
Abstrak: Penulisan ini membahas tentang pentingnya peran Pengadilan Agama dalam praktik penyelesaian sengketa ekonomi syariah. Memberikan perluasan kewenangan pada Pengadilan Agama untuk memeriksa serta memutuskan dalam sengketa ekonomi syariah diatur dalam Pasal 49 UUD No 3 Tahun 2006. Prinsip ekonomi syariah sudah diatur di dalam UUD No. 40 Thn 2007 dan UUD No. 10 Tahun 1998 tentang peraturan Perbankan Syariah. Dan pemerintah juga sangat mendukung tentang perkembangan ekonomi syariah, hal ini yang perlu di apresiasi. Konsep atau sistem ekonomi syariah bertambah kuat setelah dikeluarkan putusan MK No: 93/PUU-X 2012 pada tanggal 29 Agustus 2013. Mahkamah Agung juga turut berasumsi membina pengadilan agama sebagai penguat atau jalur tempuh mediasi untuk penyelesaian sengketa ekonomi syariah. Dari keterangan di atas inilah prinsip, konsep dan sistem ekonomi syariah semakin kuat. Penulisan ini sangat penting, karena di dalam membahas tentang peran pengadilan agama dalam menyelesaikan sengketa-sengketa ekonomi syariah, baik mengenai pemeriksaan, kewenangan, keputusan dan hal-hal lainnya yang berkaitan didalam penyelesaian sengketa ekonomi syariah.
\end{abstract}

Kata Kunci: Pengadilan Agama, Sengketa, Praktik, Ekonomi Syariah 


\section{PENDAHULUAN}

Ajaran (syari'at) Islam merupakan langkah- langkah terbaik di dalam penyelesaian sengketa atau permasalahan dalam ekonomi syariah (Na'im, 2001:344). Ajaran ini tidak terlepas dari pada ajaran yang dibawa oleh Nabi Muhammad Saw, yang mana Nabi mulai sejak usia belia berkisar umur 12 tahun, beliau turut berdagang bersama pamannya, yaitu Abu Thalib. Nabi Muhammad SAW secara mandiri bisnis dagang beliau memulai ketika sudah masuk usia remaja, dan berdagang bersama sahabat yang bernama as-Saib, dimana as-Saib ini merupakan sahabat atau rekanan yang baik. Nabi dikenal orang yang sifatnya baik, jujur (siddiq), dan dapat dipercayai (al-amin).

Mengenai perkara sengketa ekonomi syariah ini merupakan hak atau kewenangan pengadilan agama, sesuai dengan Pasal 49 UUD No.3 Tahun 2006, yang mana bunyi pasal tersebut memberikan hak kewenangan secara luas terhadap pengadilan agama untuk memutus atau mengadili perkara penyelesaian ekonomi syariah. Dengan lahirnya Pasal 49 tersebut pengadilan negeri tidak mempunyai lagi hak atau kewenangan didalam menyelesaikan perkara atau sengketa ekonomi syariah.

Aktivitas dalam menjalankan sebuah kegiatan ekonomi syariah tidak hanya harus melakukan kegiatan usaha sesuai dengan prinsip syariah, akan tetapi juga terlibat hubungan hukum atau akibat hukum yang akan diperoleh (Antonio, 2008:213). Melalui kegiatan ekonomi apabila sudah terjadi transaksi (akad) antara salah satu pihak dengan pihak lainnya, apabila dari salah satu melakukan penipuan didalam transaksi ini bisa menimbulkan sebuah sengketa atau konflik (dispute).
Dispute merupakan perbedaan kepentingan antara salah satu pihak dengan pihak lainnya yang bisa merugikan terhadap antara keduanya, apabila terjadi kerugian atau ingkar didalam perjanjian maka akan terjadi atau timbul sebuah sengketa atau dikenal dengan wanprestasi (Nashikin, 2010:141). Selanjutnya, wanprestasi merupakan ingkar didalam perjanjian atau kelalaian pihak dalam memenuhi ketentuan yang sudah ditentukan didalam perjanjian (Eka, 2010:75).

\section{PEMBAHASAN}

\section{Sistem-sistem Ekonomi Syariah}

Diantara perbedaan yang utama dari sistem ekonomi syariah dengan ekonomi lainnya terdapat tiga karakterisitik, diantanya: Pertama, sumber utama ekonomi syariah adalah alQur'an dan Hadist. Kedua, perspektif atau pandangan sumber ekonomi syariah berdasarkan peradaban Islam yang dijadikan sebagai pertimbangan. Ketiga, tujuan ekonomi syariah untuk menghidupkan dan menemukan etika dan nilai yang diterapakan pada awal keIslaman oleh ekonomi muslim.

Dari karakteristik di atas, yang menjadi pembeda antara sistem ekonomi syariah dengan sistem ekonomi lainnya (konvensional) diantaranya yang berkaitan dengan asumsi-asumsi dasar manusia dan landasan filosofi. Menurut Karim (2004:27), ada empat landasan filosofis yang menjadi dasar-dasar perbedaan antara sistem ekonomi syariah dengan ekonomi lainnya, diantaranya:

Pertama, tentang tauhid (ketentuan Tuhan), ini merupakan landasan yang paling utama di dalam sistem ekonomi syariah. Dengan landasan tauhid inilah ekonomi muslim meyakini bahwa segala sesuatu yang ada di bumi termasuk rezeki (ekonomi) ini sudah 
diatur oleh Allah SWT (tauhid rububiiyah), dan juga harus taat dengan semua yang telah ditentukan oleh Allah Swt, ketaatan ini mencakup dengan halhal moral dan etika (tauhid uluhiiyah).

Kedua, mengenai keadilan dan keseimbangan, di dalam Al-Qur'an mengenai keadilan dan keseimbangan sudah dijelaskan bahwa Allah SWT mencintai dan senang terhadap orangorang yang belaku (menjalankan) adil. Ini merupakan syarat-syarat kesejahteraan masyarakat yang dicapai.

Ketiga, tentang kebebasan, yang dimaksudkan dengan kebebasan disini adalah setiap manusia bebas dalam melakukan kegiatan dan mengembangkan ekonomi selama tidak ada hukum yang melarangnya. Sesuai dengan kaidah Ushul Fikih yang dikutip dari Azam (1999:73):

$$
\text { الاصل في الاشياء الإباحة حتى يدل الدليل على }
$$

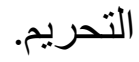

"Hukum asal dari segala sesuatu adalah boleh (mubah) selama tidak ada dalil yang melarangnya".

Keempat tentang pertanggung jawaban, manusia dimuka bumi merupakan hamba atau khalifah yang memegang amanah dari Allah SWT. Di dalam melakukan kegiatan ekonomi sudah diberikan keluasan di dalam memilih yang akan menjadi kebaikan terhadap dirinya, akan tetapi semua kegiatan manusia baik kecil maupun besar akan diminta pertangung jawaban.

Dari landasan filosofis yang empat diatas inilah yang menjadikan sistem ekonomi syariah mempunyai ciri khas keistimewaan daripada sistem ekonomi lainnya (konvensional).

\section{Proses Penyelesaian Sengketa Ekonomi Syariah Di Pengadilan Agama.}

Proses penyelesaian sengketa dalam ekonomi syariah terdapat pada pasal 49 UUD No.3 tahun 2006, yang mana pasal ini merupakan hasil amandemen UUD No.7 tahun 1989. Dan ditegaskan lagi pada Pasal 55 ayat 1 UUD 21 tahun 2008.

Pasal ini menjelaskan bahwa apabila terjadi sebuah sengketa di dalam perbankan syariah, maka jalan penyelesaian sengketa tersebut diajukan kepada Pengadilan Agama, yang mana Pengadilan Agama sudah mempunyai kewenangan dan hak untuk menerima, mengadili dan meyelesaikan atau memutus perkara sengketa tersebut (Naishikin, 2010:141).

Seperti yang diketahui dalam setiap menangani perkara sengketa, terlebih dahulu hakim selalu dituntut untuk mengetahui dan mempelajari secara cermat tentang substansi perkaranya. Menurut Mardani (2011:27), ada beberapa hal yang berkaitan khususnya dengan perkara ekonomi syariah yang diperiksa dan diperhatikan, diantaranya: Pertama perkara tersebut terlebih dahulu harus dipastikan dan perkara tersebut bukan perkara perjanjian yang bisa mengakibatkan klausula arbitrase. Kedua, harus pelajari secara cermat perjanjian (akad) yang mendasari kerja sama antara para para pihak.

Terdapat beberapa langkah dalam proses penyelesaian sengketa ekonomi syariah di Pengadilan Agama, diantaranya:

1. Subjek Hukum

Subjek hukum merupakan para pihak yang mempunyai hak dan kewajiban. Yang dimaksudkan subjek hukum dalam pembahasan ini adalah para pelaku hukum yang terikat atau 
terlibat didalam proses sengketa perbankan syariah. Jadi pihak-pihak yang terlibat melakukan sengketa atau tindakan hukum di dalam perbankan syariah disebut para pelaku hukum, pihak tersebut bisa perorangan atau kelembagaan. Diantara beberapa tindakan hukum ini bisa berupa sebuah perjanjian atau akad syariah yang mana pihak-pihak tersebut menjadi terlibat atau terikat daripada hasil tindakannya (Joni, 2008:22).

Perlu diketahui juga bahwa subjek hukum yang terdapat dalam perbankan syariah tidak mengatur tentang kriteria pihak-pihak dalam beragama, akan tetapi mengatur prinsipprinsip syariah tentang dasar operasionalnya. Sehingga semuanya bisa melakukan perjanjian atau akad perbankan syariah baik beragama Islam atau tidak, sesuai dengan kehendak atau kehendak yang telah disepakati.

Seseorang atau badan hukum yang beragama selain Islam yang telah melakukan kegiatan perbankan syariah dengan sendirinya dan dia sudah menyatakan menundukkan diri dengan usaha atau kegiatan perbankan syariah yang menggunakan prinsip-prinsip syariah, apabila terjadi sengketa maka badan hukum atau orang tersebut sudah termasuk yang dimaksudkan didalam Pasal 2 atau Pasal 49 Undang-Undang Pengadilan Agama (UUPA) yang mana mereka atau pihak tersebut bisa mencari sebuah keadilan atau menyelesaiakan sengketanya melalui Pengadilan Agama. Untuk proses penyelesaian sengketanya baik secara personal bisa secara langsung atau bisa mewakilkan terhadap kuasa hukumnya atau kuasa insidentil mereka (Naishikin, 2010:143).

\section{Proses Penyelesaian Sengketa Ekonomi Syariah}

Di dalam Pasal 2 Peraturan Mahkamah Agung (PERMA) No.14 Tahun 2016 terdapat dua penanganan untuk penyelesaian sengketa ekonomi syariah, diantaranya: pertama, Acara Biasa, yang kedua Acara Sederhana.

\section{Penanganan}

penyelesaian

perkara ekonomi syariah melalui acara biasa tetap mengambil atau mengacu pada undang-undang yang berlaku. Dan penganganan penyelesaian perkara ekonomi syariah melalui acara sederhana mengacu terhadap Peraturan Mahkamah Agung (PERMA) No. 2 Tahun 2015, yaitu tentang bagaimana cara gugatan sederhana atau sering dikenal dengan istilah small claims court.

Dalam ketentuan penanganan perkara ekonomi syariah acara sederhana, perkara cidera atau perbuatan melawan hukum dengan nilai gugatan sebesar 200.000.000. Pihakpihak yang berdomisili atau bertempat tinggal di suatu wilayah hukum yang sama, baik penggugat atau tergugat tidak diperbolehkan lebih dari satu, alamatnya harus jelas dan juga diketahui, didalam proses pendaftaran perkaranya harus menggunakan blanko gugatan, untuk pengajuan bukti-buktinya harus bersamaan didalam pendaftaran perkara, sidang paling lama 2 hari, gugatan dikatakan gugur apabila penggugat tidak hadir pada sidang pertama, kecuali dengan adanya alasan yang sah atau dibenarkan, proses didalam pemeriksaan hanya ada dua yaitu: gugatan dan jawaban, 25 hari waktu penyelesaian perkara dimulai sejak sidang pertama. Didalam penyampaian sebuah putusan paling lama 2 hari setelah putusan sudah diucapkan, tidak ada istilah upaya banding atau kasasi, yang ada hanya upaya hukum dalam pengajuan hukum 
keberatan yang diajukan selama 7 hari setelah diucapkannya sebuah putusan atau pemberitahuan putusan (PERMA RI No.2 Tahun 2015).

Pengadilan agama memiliki dua cara dalam menentukan atau menangani perkara ekonomi syariah, diantaranya yaitu: Pertama, penggugat dapat mengajukan gugatannya di wilayah tempat tinggal atau kediamannya. Kedua, tergugat dapat mengajukan gugatannya di wilayah tempat tinggal atau kediamannya. Apabila pihak tergugat lebih dari satu orang atau lebih, maka proses gugatannya tersebut dapat diajukan kepada pengadilan agama di tempat tinggalnya (Sarwono, 2011:64).

Para pihak dalam pembuatan surat gugatannya, maka pihak tersebut harus memenuhi ketentuan syaratsyarat formil gugatan, sehingga bisa terpenuhi formulasi gugatan yang jelas. Dan beberapa gugatan ini bisa diajukan secara tertulis atau secara lisan (Bambang, 2013:20), diantara syaratsyarat formil yaitu:

1. Identitas Para Pihak

Identitas disini meliputi: nama dan gelar atau julukan, bin atau bintinya, umur, agama, pekerjaan tempat tinggal terakhir dan status sebagai penggugat atau tergugat. Apabila diakumulasi secara subjektif diantaranya: penggugat I, penggugat II dan seterusnya. Dan apabila terdapat pemberian kuasa, maka harus mencantumkan identitas pemegang kuasanya (Rasyid, 1991:64).

\section{Fundamentum Petendi}

Yang berarti dasar gugatan atau dasar tuntutan (grondslag van de lis). Terdapat beberapa istilah yang sering digunakan dalam praktik peradilan yaitu: posita gugatan atau positum, di Indonesia lebih dikenal dengan dalil gugatan. Posita atau dalil gugatan merupakan landasanlandasan pemeriksaan dan proses dalam proses penyelesaian perkara. Pemeriksaan dan penyelesaian tidak diperbolehkan menyimpang dari pada dalil-dalil gugatan.

Mengenai hal-hal perumusan dalil gugatan terdapat dua teori, yaitu:

a. Teori Substansi (substantierings theorie).

Teori ini menjelaskan tentang dalil gugatan, disini tidak cukup hanya dengan merumuskan peristiwaperistiwa hukum yang menjadi dasar dalam tuntutan saja, akan tetapi juga harus ada penjelasan tentang fakta-fakta yang mendahului peristiwa hukum yang menjadi penyebab timbulnya didalam peristiwa hukum tersebut.

b. Teori Individualisasi (individualisering theorie).

Teori ini menjelaskan tentang peristiwa atau kejadian hukum yang dikemukakan dalam gugatan, disini harus dengan jelas memperlihatkan hubungan hukum (rechtsverhouding) yang menjadi dasar-dasar dalam tuntutan (Harahap, 2004:57).

\section{Petitum Gugatan}

Petitum merupakan pokok-pokok didalam tuntutan gugatan yang diajukan. Tuntutan ini didasarkan atas dalil-dalil gugatan, dengan istilah lain antara petitum dan posita harus berkesesuaian, apalagi saling bertolak belakang (Harahap, 2004:57). 


\section{Proses Pemeriksaan Sengketa Ekonomi Syariah Di Pengadilan Agama}

Gugatan yang telah diajukan selanjutnya akan diproses oleh pengadilan agama, dengan beberapa tahapan yaitu:

1. Tahap-tahap Pra Persidangan

a. Pendaftaran perkara

Pihak-pihak yang telah membuat surat gugatan dapat mengajukan gugatan tersebut kepada pihak kepaniteraan di pengadilan agama, baik tempat tinggal dirinya atau tempat tinggal pihak lawann yang sesuai dengan isi perjanjian dan kesepakatannya.

Pendaftaran ini bisa datang langsung ke pengadilan agama atau bisa melalui pendaftaran elektronik (e-Court) seperti yang telah diatur dalam PERMA No. 14 Tahun 2016.

b. Penetapan majelis hakim.

Ketua pengadilan agama menunjuk majelis hakim untuk memeriksa suatu perkara yang telah diajukan ke pengadilan agama, ini merupakan hak dan kewenangan daripada ketua pengadilan agama.

c. Penetapan Panitera Sidang/ Panitera Pengganti.

Ketua Majelis yang diperintahkan oleh Ketua Pengadilan Agama menunjuk kepada panitera sidang atau panitera pengganti untuk membuat berita acara sidang atau mencatat dalam jalannya persidangan dan mematuhi atau melaksanakan semua yang diperintahkan oleh hakim dalam proses menyelesaikan jalannya perkara tersebut (Undang-
Undang Nomor. 4 tahun 2004 tentang Kekuasaan Kehakiman).

d. Penetapan hari persidangan dan pemanggilan para pihak.

Pada sidang pertama yang sudah ditetapkan, jurusita pengadilan agama diperintahkan oleh ketua majelis hakim untuk memanggil kedua belah pihak supaya menghadiri pada waktu, hari dan tempat yang telah ditentukan. Waktu hari proses pemanggilan antara kedua belah pihak dan hari persidangan tidak kurang dari 3 hari. Panggilan ini dikategorikan dengan istilah resmi dan patut apabila suratsurat tersebut sudah memenuhi ketentuan-ketentuannya.

2. Tahap Persidangan

Dalam sidang pemeriksaan sengketa ekonomi syariah di pengadilan agama sifatnya terbuka untuk umum, kecuali ada undangundang yang menetapkan sidang tertutup. Ketentuan ini sesuai dengan pasal 19 ayat 1 undangundang No 4 Thn 2004, yang telah diubah dalam Pasal 13 undangundang No 48 Thn 2009 tentang Kekuasaan Kehakiman. Ketentuan pasal ini telah berlaku dalam sidang pemeriksaan sengketa perbankan syariah, dikarenakan belum adanya ketentuan-ketentuan yang ditetapkan dalam peraturan yang berkaitan tentang perbankan syariah ataupun didalam tata cara penyelesaian di pengadilan agama.

a. Acara pemeriksaan sidang istimewa.

Dalam hal ini dapat dilakukan oleh Pengadilan Agama, apabila terjadi tiga hal kemungkinan pada perkara 
Pertama: Terhadap perkara yang digugurkan. Kedua, Terhadap perkara yang dibatalkan. Ketiga, Terhadap perkara verstek.

b. Acara pemeriksaan sidang biasa.

Dalam hal ini mengenai sengketa ekonomi syariah terjadi apabila kedua belah pihak yang bersengketa atau melalui kuasanya hadir pada persidangan pertama atau persidangan selanjutnya.

Sebelum ke persidangan, dilakukannya upaya perdamaian melalui mediasi, yang ditetapkan dalam Peraturan Mahkamah Agung (PERMA) Nomor 1 Tahun 2008 tentang Prosedur Mediasi di Pengadilan, dengan adanya Peraturan Mahkamah Agung (PERMA) tersebut, mediasi yang awalnya merupakan salah satu bentuk alternatif penyelesaian sengketa di luar pengadilan atau non litigasi menjadi suatu cara penyelesaian sengketa yang integral dengan proses penyelesaian litigasi di pengadilan.

Adapun tahap prosedurprosedur mediasi menurut PERMA sebagai berikut:

1) Pra Mediasi

Berdasarkan Pasal 7 ayat 5 , tentang kewajiban menunda sidang pertama untuk upaya mediasi. Pihak diberi kebebasan dalam memilih mediator yang ada di luar Pengadilan (advokat, akademisi hukum), jasa biaya ditanggung kedua belah pihak, apabila mediator yang dipilih dari Pengadilan, maka tidak ada uang jasa. Apabila dalam jangka waktu paling lama 2 hari tidak mencapai kesepakatan untuk memilih mediator, maka sesuai didalam ketentuan Pasal 11 ketua majelis segera menunjuk hakim untuk menjadi mediator.

2) Proses Mediasi

Proses mediasi di Pengadilan jangka waktu yang ditetapkan adalah 40 hari sejak mediator dipilih oleh para pihak, dan ditunjuk oleh Ketua Majelis. Mengenai batas waktu tersebut dapat ditambah sampai 4 hari sesuai kesepakatan para pihak yang bersengketa. Dalam proses mediasi, mediator merupakan pihak yang harus bersifat netral dan tidak memihak diantara kedua para pihak yang bersengketa (Pasal 1 ayat 6 PERMA No.1 Tahun 2008).

3) Hasil Mediasi

Kedua belah pihak yang bersengketa apabila berasil maka keduanya harus mebuat kesepakatan-kesepakatan perdamaian tanda tangan secara tertulis (hitam diatas putih) dan juga ditanda tangani oleh mediator, dan juga dilengkapi dengan akta perdamaian, keduanya wajib untuk melakukan atau membuat akta perdamaian tersebut.

Apabila hasil dari mediasi tersebut gagal, maka mediator wajib menyatakan secara tertulis bahwa proses mediasi 
telah gagal dan memberitahukan hal tersebut kepada Hakim, sesuai Pasal 18 Perma No 1 Thn 2008.

Di dalam persidangan acara biasa terdapat beberapa tahapan, yaitu: pemeriksaan pokok perkara dan kesempatan saling menjawab antara para pihak. Adanya acara saling menjawab dan replik duplik dalam pengadilan agama, hal tersebut bertujuan untuk memberikan kewenangan hak perlakuan hukum yang sama terhadap para pihak dalam proses pemeriksaan persidangan.

Kemudian dilanjutkan dengan acara pembuktian, dalam hal ini pembuktian dengan adanya dalil-dalil gugatan, jika gugatan tesebut dibantah oleh pihak lawan, maka pihak lawan wajib memberikan sebuah alat bukti terhadap bantahan tersebut. Alat-alat bukti sengeketa ekonomi syariah dalam pasal 164 HIR dan pasal $1866 \mathrm{KUH}$ Perdata, yaitu: saksi, alat bukti surat atau tulisan, sangkaan, pengakuan dan sumpah.

Adapun akhir acara dari pemeriksaan dalam pengadilan agama diantaranya: Pertama, kedua belah pihak memberikan konklusi atau kesimpulan. Kedua, masing-masing para pihak memberikan pendapat akhir mengenai pokok-pokok sengketa atau perkara yang sudah diperiksa didalam permohonan atau tuntunan yang telah diajukan.

Ada dua bentuk putusan acara biasa dalam penyelesaian sengketa ekonomi syariah, yaitu: Pertama, putusan yang menyatakan bahwa gugatan penggugat dikabulkan baik sebagian ataupun seluruhnya. Kedua, putusan yang menyatakan bahwa gugatan penggugat di tolak (Harahap, 2004:896).
Dengan adanya putusan upaya hukum didalam pemeriksaan acara biasa, para pihak dapat mengajukan upaya hukum banding dan para pihak tidak diperkenankan terhadap putusan sengketa ekonomi syariah mengajukan upaya hukum kasasi ataupun peninjauan kembali.

Diantara ketentuan-ketentuan upaya hukum banding adalah: Pertama, kedua belah pihak wajib hadir disaat diucapkannya sebuah putusan, jangka waktu 14 hari yang diberikan untuk melakukan upaya hukum banding, hari tersebut terhitung setelah dinyatakan putusan. Kedua, apabila dari salah satu pihak tidak hadir saat diucapkan putusan, maka upaya banding tersebut bisa dilakukan oleh pihak yang tidak hadir didalam waktu 14 hari terhitung setelah hari disampaikannya isi putusan (Harahap, 2004:896).

\section{SIMPULAN}

Pengadilan Agama merupakan hak dan kewenangan didalam penyelesaian sengketa ekonomi syariah. Hak dan kewenangan pengadilan agama dalam hal ini menerima, mengadili dan menyelesaikan sengketa yang didasarkan kepada point 1 pasal 49 Undang-undang Nomor 3 Tahun 2006 tentang perubahan Undang-undang Nomor 7 Tahun 1989 yang menjelaskan tentang peradilan agama, dan ditegaskan kembali pada pasal 55 ayat 1 Undangundang No 21 Thn 2008 tentang perbankan syariah, yang menyatakan apabila terjadi sebuah sengketa dalam perbankan syariah, maka penyelesaian sengketanya harus diajukan ke pengadilan agama.

Di dalam persidangan acara biasa terdapat beberapa tahapan, yaitu: pemeriksaan pokok perkara dan kesempatan saling menjawab antara 
para pihak. Adanya acara saling menjawab dan replik duplik dalam pengadilan agama, hal tersebut bertujuan untuk memberikan kewenangan hak perlakuan hukum yang sama terhadap para pihak dalam proses pemeriksaan persidangan. Kemudian dilanjutkan dengan acara pembuktian, dalam hal ini pembuktian dengan adanya dalil-dalil gugatan, jika gugatan tesebut dibantah oleh pihak lawan, maka pihak lawan wajib memberikan sebuah alat bukti terhadap bantahan tersebut. Alat-alat bukti sengeketa ekonomi syariah dalam pasal 164 HIR dan pasal $1866 \mathrm{KUH}$ Perdata, yaitu: saksi, alat bukti surat atau tulisan, sangkaan, pengakuan dan sumpah.

\section{DAFTAR RUJUKAN}

Antonio, Muhammad Syafi'i. (2008). Bank Syariah dari Teori ke Praktek, Cetakan Keduabelas. Jakarta: Gema Insani.

Azam, Muhammad Abd al-Aziz. (1999). Qawa'id al-Fiqh al-Islamiy. Kairo: ar-Risalah al-Dauliyah.

Bambang, Sugeng. (2013). Pengantar Hukum Acara Perdata. Jakarta: Prenada Media Group.

Eka An, Aqimuddin. (2010). Solusi Bila Terjerat Kasus Bisnis. Jakarta: Raih Asa Sukses.

Harahap, Yahya. (2004). Hukum Acara Perdata. Jakarta: Sinar Grafika.

Joni, Emirzon. (2008). Hukum Bisnis Indonesia. Jakarta: CV.Literata Lintas Media.

Karim, Adiwarman. (2004). Bank Islam, Analisis Fiqih dan Keuangan. Jakarta: Rajagrafindo.

Ketentuan memilih Pengadilan Agama sebagai tempat pengajuan gugatan dapat dilihat dalam ketentuan Pasal 142 ayat (1) dan (2) RBg.
Mardani. (2011). Hukum Ekonomi Syari'ah Di Indonesia. Bandung: Refika Aditama.

Na'im, Mochtar. (2001). Kompendium Himpunan Ayat-ayat Al-Qur'an yang berkaitan dengan Hukum. Jakarta: Hasanah.

Nasikhin, Muh. (2010). Perbankan Syariah dan Sistem Penyelesaian Sengketanya. Kuala Tunggal: Fatawa.

Peraturan Mahkamah Agung (PERMA) RI No. 1 Tahun 2008 Tentang Prosedur Mediasi di Pengadilan. Pasal 1 ayat (6).

Peraturan Mahkamah Agung (PERMA) RI No. 2 Tahun 2015 Tentang Tata Cara Penyelesaian Gugatan Sederhana.

Putusan Mahkamah Konstitusi Nomor 93/PUU-X/2012.

Rasyid, A Roihan. (1991). Hukum Acara Peradilan Agama. Jakarta: Rajawali.

Sarwono. (2011). Hukum Acara Perdata. Jakarta: Sinar Grafika.

Undang-Undang Nomor 21 Tahun 2008 tentang Perbankan Syari'ah.

Undang-Undang Nomor 3 Tahun 2006 tentang Perubahan Atas Undangundang Nomor 7 Tahun 1989 tentang Peradilan Agama.

Undang-Undang RI Nomor 48 Tahun 2009 Tentang Kekuasaan Kehakiman. 